\title{
SUSTAINABLE AND COMMUNITY-BASED TOURISM MODELS FOR ALLEVIATING POVERTY IN CITARUM BASIN
}

\author{
Pius Suratman Kartasasmita \\ Department of Public Administration \\ Parahyangan Catholic University \\ Bandung, Indonesia \\ pius@home.unpar.ac.id
}

\author{
Janelle Falconer \\ B. Arts/Science, B. International Studies \\ University of the Sunshine Coast \\ Queensland, Australia \\ janellesfalconer@gmail.com
}

\begin{abstract}
Empirical evidence signifies that poverty is one of the critical public issues within Citarum River Basin Communities (CRBC). Rates exceeding national averages demonstrate poverty levels greater than $25 \%$ in 8 of its 11 districts. This paper aims to explore the extent to which Sustainable Tourism Models (STM) could be potentially fostered as a feasible means of alleviating poverty in the Citarum River Basin (CRB), through policy endorsement and collective actions. Conceptual frameworks of Mills (1959), Hardin (1968) and Ostrom (1990) are used in defining, identifying and signifying poverty as a truly critical public issue where as the Framework Institute's approach is used as a basic logical step in framing the issue into both policy cycles and collective community actions. Relevant previous study on STM and secondary assessable empirical data on poverty within CRBC are reviewed. It is expected that the paper contributes to providing conceptual as well as policy frameworks for developing strategies to alleviate poverty in CRBC. It also suggests how collaborative governance in fostering STM through effective government policy, corporate social responsibility as well as collective actions of local communities, maybe initiated.
\end{abstract}

Keywords-Sustainable Tourism Model (STM), Citarum River Basin Communities (CRBC), Poverty Alleviation, Sustainable Development Goals (SDGs), Indonesia.

\section{INTRODUCTION}

The CRB is the most strategic river basin in Indonesia covering more than $13000 \mathrm{~km} 2$ with a population of nine million. The Citarum is the longest river in West Java spanning 297 kilometres. Poverty is well above the national average. Poverty rates in eight of the CRB's eleven districts exceed $25 \%$. It comprises of major industrial and urban centres including Bandung Indonesia's fourth largest city and provincial capital of West java and satellite industrial parks to the west of Jakarta. The CRB supplies more than $80 \%$ of Jakarta's raw water and is the site of three major dams and three large multipurpose reservoirs (Sinaga, 2013). Bandung and Greater Jakarta regions are supplied electricity from three hydroelectric power plant dams situated along the river. It is one of the most polluted river basins in the world and is vital to the lives of the people of West Java, supporting agriculture, water supply, fisheries, industry, sewerage, and electricity. Irrigation from the Citarum River supplies the vast productive rice paddies of the northern West Java lowlands. Irrigation, domestic and industrial wastes are discarded into the Citarum River lowering its water quality. Factories and farmers discharge their waste products and manure into the water, adding to pollution from household waste. The river water has high turbidity with suspended solids (Banerji et al., 2013).

Based on SUSENAS 2004 poverty data, poverty in the districts and municipalities in the CRB is as follows: 2.8 million people or $9.7 \%$ of the basin population with poverty levels of the total populations ranging from $1.5 \%$ to $4.8 \%$ in the totally urban areas and $2.9 \%$ to $26.4 \%$ in the districts, a mix of urban and rural populations. Access to clean water varies in the urban areas between $77-97 \%$ of the total population. In the districts it lies in the range of $37-87 \%$. Access to clean water is significantly lower amongst the poor in all areas except Bekasi and Cianjur where levels between poor and non-poor are similar. Households with toilets in the municipalities vary between $94-100 \%$ of total population, whereas in the districts it is $53-89 \%$. In many areas households with toilets are significantly lower amongst the poor, but in Bekasi, Depok, Cianjur and Subang it is similar between poor and non-poor. There is a general trend between low poverty and high coverage of water and toilet facilities, and higher poverty and lower coverage of facilities (Figure 1) (ADB, 2007).

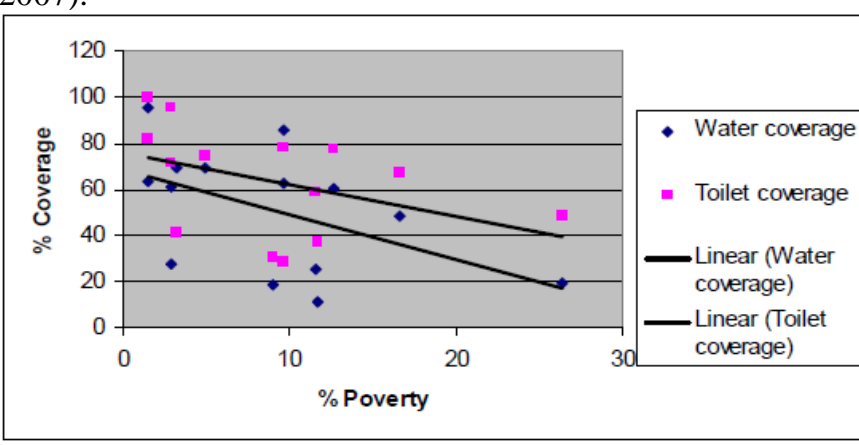

Fig.1. River Basin Poverty and Coverage of Households with Clean Water and Toilets (ADB 2007)

Recent national poverty statistics demonstrate that in 2004 , districts within the CRB had a higher poverty rate of up to 
$26.4 \%$ in comparison with the national 2014 relative poverty rate of 11\% (Table 1) (Piasto, 2015).

Table 1. Poverty Incidence 2006-2014, Indonesia (Piasto, 2015)

\begin{tabular}{|c|c|c|c|c|c|c|c|c|c|}
\hline & 2006 & 2007 & 2008 & 2009 & 2010 & 2011 & 2012 & 2013 & 2014 \\
\hline Relative Poverty (\% of population) & 17.8 & 16.6 & 15.4 & 14.2 & 13.3 & 12.5 & 11.7 & 11.5 & 11.0 \\
\hline Absolute Poverty (in millions) & 39 & 37 & 35 & 33 & 31 & 30 & 29 & 29 & 28 \\
\hline $\begin{array}{c}\text { Rural Poverty (\% living below rural } \\
\text { poverty line) }\end{array}$ & 21.8 & 20.4 & 18.9 & 17.4 & 16.6 & 15.7 & 14.3 & 14.4 & 13.8 \\
\hline $\begin{array}{l}\text { Urban Poverty (\% living below } \\
\text { urban poverty line) }\end{array}$ & 13.5 & 12.5 & 11.6 & 10.7 & 9.9 & 9.2 & 8.4 & 8.5 & 8.2 \\
\hline
\end{tabular}

In an attempt to address the issue of poverty in the CRB, this paper presents the following problem statements. An investigation will be made of 'public issues' and how they should be defined, identified and framed along with an analysis of whether intervention is best through public policy making processes or through egalitarian collective actions or both. Furthermore consideration will be given to bottom up governance policy prescriptions based on social-ecological sustainability fitting with a sustainable tourism model as an instrument to alleviate poverty in the CRB.

\section{DEFINING AND IDENTIFYING PUBLIC ISSUES}

Mills (1959) viewed public issues as those that transcend the individual and involve institutions and society as a whole. Public issues are consequences of the collapse of opportunities and social structures with mismanagement of society being the cause. The sociological imagination calls for a sociological vision, a way of looking at the world that sees links between apparently private problems and important social issues which cannot be solved by the individual (Mills, 1959). The "Sociological Imagination" demonstrates why sociologists need to be critical of the bureaucratization of sociological research and how types of government, bureaucracies and cultural influences impact public issues.

In human terms, poverty is by far the over-riding public issue in the CRB and is linked inextricably with severe environmental degradation. Efforts to clean the river need boosting and more community involvement. There are some community based tourism activities. By investigating further potential and existing sustainable tourism models, poverty reduction maybe in sight for these communities. Interrelated issues which need consideration are: water quality, pollution, health issues, corporate responsibility by industrial polluters, deforestation, unemployment, and over population.

The CRB reflects a commons tragedy on an immense scale. Garret Hardin's (1968) concept of the Tragedy of the Commons proposed that the problem of dividing resources should be done in a way that suits human nature. His argument was that shared resources tend inevitably to be overused and ruined resulting in tragedy when each individual is locked into a system that necessitates an increase in herd or catch (in the case of pastures and fisheries) without limit in a world that is finite. Pollution is the same tragedy in reverse where unlimited waste is put into the commons. Hardin emphasised the need for top down intervention particularly in relation to population control (Hardin, 1968; Heywood, 2014). He drew attention to the concept of a 'class of human problems' that have no technical solutions where morality must be drawn upon.

Elinor Ostrom's (1990) responded to Hardin's 'tragedy', promoting grass roots, community approaches as alternative policy prescriptions to centralised and privatised top down approaches. She documented many societies who managed Common Pool Resources (CPR) through diverse, bottom up, institutional arrangements (Ostrom, 1990; Heywood, 2014). Community ownership has for millennia played out in indigenous societies where environmental stewardship has been integral to cultural practices and food security, as seen with the Aboriginal Australians and indigenous communities in parts of Indonesia. Through the practice of indigenous traditional ecological knowledge (TEK) commons tragedies maybe avoided (Berkes and Berkes, 2009). Local communities and indigenous communities are increasingly combining TEK with ecotourism activities to enhance livelihoods, preserve culture and support biodiversity conservation (Blangy and Mehta, 2006; Willis, 2011).

Public issues maybe identified conceptually, empirically and through policy approaches. Hilangnya konsep publik or the loss of the public from the minds of officials and decision makers needs addressing across democracies and other forms of governance worldwide (Kartasasmita, 2006). Conceptual frameworks such as those proposed by Mills, Hardin and Ostrom are strengthened if supported with empirical evidence. However if data demonstrates a small proportion of a community suffering from the effects of certain pollutants for example, it doesn't mean that the pollution is not causing a public issue, because in this case any victims irrespective of the number are too many. The policy approach identifies issues by government policy and regulations. Regulations however may state what the public issue is but it might not link to the real issue. Types of government and cultural influences impact public issues therefore public policy should accurately identify public issues and be framed and respond in ways most suited to society's needs (Kartasasmita, 2006).

\section{FRAMING PUBLIC ISSUES INTO POLICY AND COLLECTIVE ACTION}

Frames are socially shared organizing principles that are persistent over time and symbolically and meaningfully structure the social world (Reese, 2001). In conjunction with framing public issues using The Framework Institute (TFI) Approach, framing of public issues in Indonesia should consider the context-dependence of communication combined with the dynamic relationships of socio-ecological systems (McGreavy et al., 2013) which are amplified by Indonesia's cultural diversity and high-context language and embedded in social collectivism (Barry, 2011; Burton, Westen and 
Kowalski, 2012). Framing strives therefore for behaviour change through diffusion of ideas and village acceptance which will build capacity through shared knowledge and skills. Issues important to local people are voiced increasing empowerment leading to sustainable and positive behaviour change.

There is no empirical evidence demonstrating the efficacy of centralisation or privatisation in the governance of CPR. Both of these policy prescriptions disempower traditional resource users and their implementation is expensive. Solutions for the CRB do not only lie in implementing technical interventions but also in addressing social and administrative issues through policy responses and community development approaches (Kartasasmita, 2017).

The Government of Indonesia attempts to address public issues in CRB through: legal effluent and river water standards, understandings with industry about pollution control and monitoring programs. Although the quality of the river continues deteriorating at an alarming rate exacerbating impacts of poverty (JT2PC, n.d.). Jasa Tirta II Public Corporation (JT2PC) has the responsibility to maintain supply of water at a good quality (JT2PC, n.d.).

Ostrom (1990) in Governing the Commons illustrates how CPR problems are solved by voluntary organizations rather than by coercive state or top down regulations. This paper supports alternative policy prescription, a community approach of common property regimes toward achieving sustainable management of the Citarum River Catchment. It is proposed that if this approach is combined with well implemented top down governance, reductions in poverty could be achieved. This to some degree is being implemented in the Citarum River Basin through a program that is utilising a loan from the Asian Development Bank (ADB) which has stimulated education and recycling as cost-effective methods of improving the region's notoriously polluted rivers. Improved livelihoods, incomes and the health of communities are apparent as a result of the program (ADB, 2014).

Ostrom's (1990) 'Institutional Analysis and Development' (IAD) Framework is provided in Figure 2. If integrated into a sustainable tourism model (STM), this paper suggests that community wellbeing could be significantly enhanced. A small scale STM example is provided in Figure 3 (Purwanto, n.d.). Sustainable management of the natural environment and poverty alleviation through ecotourism by local communities exemplifies ways community based approaches assist social systems' resilience to changing environmental conditions by combining private, state and community management of the commons (Falconer, 2015). The management of the irrigation commons in post-war Japan and a policy alternative termed 'state-reinforced self-governance' demonstrates how a

financially technologically, statutorily, and politically strong state strategically assists, rather than coerces, selfgovernance in order to avert a commons tragedy (Sarker, 2013).

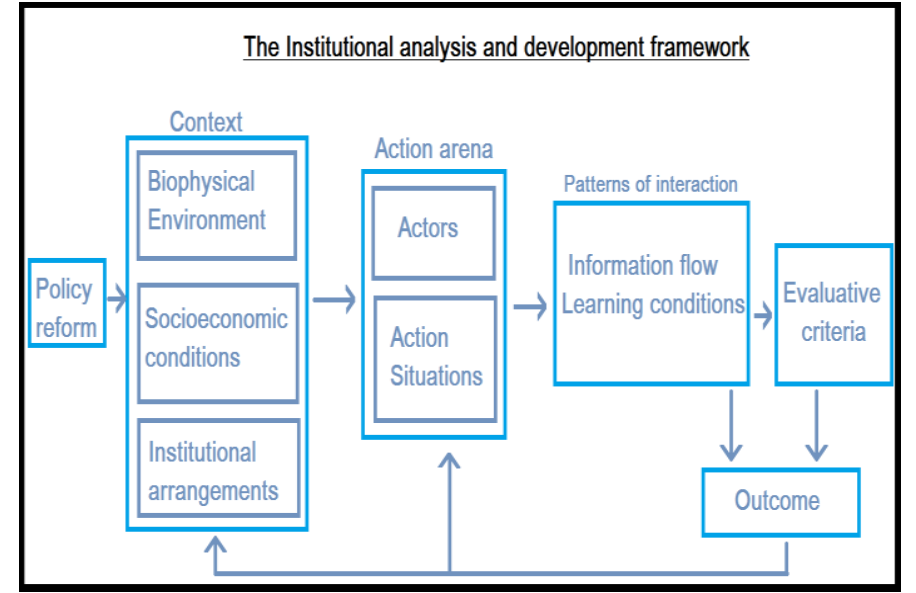

Fig. 2. Ostrom's IAD Framework (Ostrom, 1990)

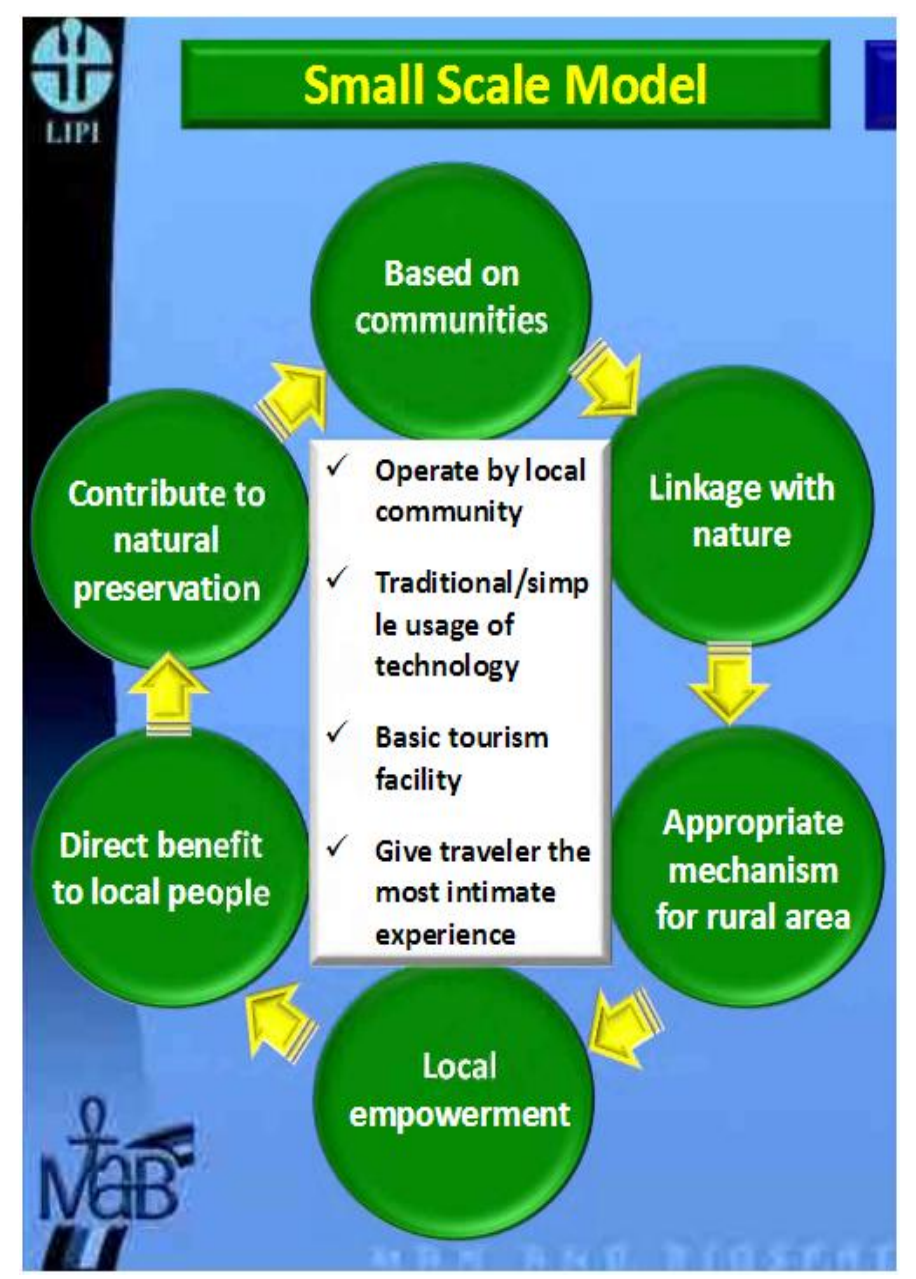

Fig. 3. Small Scale Community Based Tourism Model (Purwanto, n.d.) 


\section{DEFINING SUSTAINABLE AND COMMUNITY BASED TOURISM}

This paper advocates that sustainable tourism is a key indicator of social and ecological sustainability. The United Nations World Tourism Organisation (UNWTO) defines sustainable tourism as 'tourism that takes full account of its current and future economic, social and environmental impact, addressing the needs of visitors, the industry, and the environment and host communities' (UNWTO, 2004). Ecologically sustainable tourism development may be implemented to safeguard ecosystems, and enhance local societies and economies through ecotourism initiatives and programs (Willis, 2011; Swarbrooke, 2002). The International Ecotourism Society (TIES) recently revised its definition of ecotourism as "responsible travel to natural areas that conserves the environment, sustains the wellbeing of the local people and involves interpretation and education" specifying that education is to staff and guests. It is non consumptive and non-extractive, creates an ecological conscience and holds eco-centric values and ethics in relation to nature (TIES, 2015).

CBT is a type of sustainable tourism in a community setting whose initiatives aim to involve local community members in the operation and management of small scale tourism ventures as a means of alleviating poverty and providing alternative income sources for local people (SNV, 2007). CBT applies the objectives of sustainable tourism emphasising community engagement and development, managed and owned by the community for the community. Benefits of CBT encompass community development, capacity building, local control and local enterprise development, sustainable livelihoods and poverty alleviation (Hall, 1996; Cole, 2006; SNV, 2007). By approaching both tourism and poverty from a sustainability perspective and utilising sustainable tourism as an indicator of both social and ecological sustainability, measurable benefits may be realised.

\section{SUSTAINABLE TOURISM AND CBT AS ALTERNATIVE LIVELIHOODS}

Strong links between poverty and ecological degradation and public health issues in CRBC necessitate alternative livelihoods. Pollution has affected agriculture so much that farmers have sold their rice paddies for half their normal price (Noda et al., 2013; Williams, 2013). Textile factories in Bandung and Cimahi flush large quantities of toxic waste into the river (Natahadibrata, 2013). More than 2,000 industries contaminate 5,020 sq miles of the river with lead, mercury, arsenic and other toxins. Tests have found highly alkaline liquid being discharged into the Citarum River (Leahy, 2013). Textile mills are among the rice fields and houses. Heavily polluted water is discharged directly into the river at hundreds of different locations. Surface water from the river is used to irrigate rice fields and local children swim in it. Eventually surface water infiltrates groundwater, and heavy metals go into the wells of Majalaya. Water from these wells is used for washing clothes and sometimes cooking. Thousands of litres of oil spilled into the river from the storage pipes of textile company PT Central Georgette Nusantara Printing Mills in late March 2017 submerging at least two hectares of rice fields in Laksanamekar Village in West Bandung ending up in the Saguling Reservoir (Pressreader, 2017).

This concept relates to the morality of Freeman's (1983) stakeholder theory and is reflected in the case of industrial polluters neglecting to morally address impacts on local communities and the dilemma that promotes the poverty cycle. Freeman advocated that companies have moral obligations to consider and to appropriately balance the interests of all stakeholders who they are dependent upon for success. This poses the question of corporate social responsibility (CSR) and ways it may apply to assisting communities implement sustainable CBT. A 'stakeholder' is 'a person, group or organization that has interest, concern or a stake in a business or corporation (Carroll and Buchholtz, 2015).

The local communities are placed in situations where many must choose between living in poisonous environments or in poverty without work at the textile factories or in the associated economy. Community division is a result which increases vulnerability to company manipulation. Hardin discusses unrestrained self-interest based on the belief that the commons is eventually being exploited, thereby gaining the greatest use, one benefits the most. While benefits are solely to the users, costs are spread among all others sharing the commons. In the case of the CRB textile companies, the government and a section of the workforce could be considered Hardin's 'users', with all others including the many members of local communities being those who share in the cost not only in financial terms but also in terms of their health (Hewson, 2013).

The problems are ongoing because pollutants attach to riverbed sediment. Data on water quality and pollution is held by the Indonesian government. Analysis of available data has linked water quality to satellite images of the area and will enable more effective research into public health and governance (Vreeman, 2017).

AHT and I-COR's (2014) report document the status of communities around the Saguling Reservoir which besides functioning as a source of electricity generation, serves as a source of income from aquaculture, agri-aquaculture, tourism, and is used for personal bathing, washing and toilet. These activities contribute to very low water quality and high pollution levels. The report also investigates the socioeconomic impacts of the reservoir's construction. Community members who transferred ownership of the land to the Saguling Project, are in some instances much worse off socioeconomically than they were before the dam. This is reflected by the involvement of many members of the scavenger community, who were previously from wealthy farming families. The construction of the Saguling Reservoir provides electricity to Java and Bali, but is unable to provide a viable existence to all those who handed over their land for the development (AHT, 2014).

\section{SUSTAINABLE TOURISM, CBT AND POVERTY ALLEVIATION}

Poverty as a public issue therefore presents as a social, ecological and economic indicator of sustainability. The gap between public issues and policy responses is clear in the case 
of poverty in the CRB. There is high potential for sustainable tourism in Indonesia to impact positively in poverty reduction, rural development, the Sustainable Development Goals (SDGs) the creation of new business opportunities and ecologically compatible employment. Sustainable tourism concerns the conservation of natural resources and social culture while distributing benefits widely among stakeholders and communities and is an important public agenda for all stakeholders at all levels in order to benefit the economy through employment, new educational opportunities and improved quality of life (Swarbrooke, 2002; ILO, 2012).

\section{CONCLUSION}

Public Issues are those that result from a mismanagement and collapse of social structures and implicate the whole society. They maybe identified conceptually, empirically and through policy approaches. When framing public issues, The Framework Institute (TFI) Approach should strive for behaviour change through diffusion of ideas and village acceptance which builds capacity through shared knowledge and skills. Issues of local importance are voiced enhancing empowerment leading to sustainable behaviour change. The commons and the social-ecological dimension present many public issues. Further to this is the need for representation of the public's voice in decision making and subsequently reflected in policy. It could be viewed that governance of CPR should therefore primarily consider the importance of bottom up approaches, accompanied by the enforcement of ecologically protective regulations and community support as positive top down contributors to governance. While poverty is a social, ecological and economic indicator of sustainability, sustainable tourism may be viewed as a key indicator of social and ecological sustainability. By understanding how sustainable tourism and community-based tourism can nurture the resilience of fragile ecosystems while simultaneously reducing poverty, responsible stewardship of the commons of the CRB for future generations could be played out successfully through a combination of 'bottom up' approaches with supportive top down governance.

\section{RECOMMENDATIONS}

The following recommendations are considered a 'launching pad' for further bottom up CBT ventures which would be anticipated to bring long term benefits and enhance beneficiaries within CRBC. Policy to support this would need fostering at national, provincial and local levels.

\section{A. Public Awareness at the local level: socio-cultural and ecological}

There is an integral need for enhanced public awareness for the improvement of domestic pollution. This can be approached through public awareness campaigns and community development programs. The priority locations for this program would consider the places of highest population densities and also targeting the communities of the Saguling Reservoir referred to in the AHT (2014) Report. This would accompany inclusion of the upper CRB in Bandung district near Purwakarta and Bekasi catchment to address pollutants in run-off especially into the Sugaling Reservior. Programs would include community education particularly of the youth and children about the history of the Citarum before the Sugaling Reservoir, to instil respect for the culture and nature of the region and to share information about rehabilitating the river to a place of beauty.

\section{B. Enforcing effective implementation of Corporate Social Responsibility}

Policy evaluation should be fostered at regional and central government levels in relation to the need to enforce existing legislation to address environmental degradation and public health. This would be with the aim to reduce pollution from textile manufacturers and other industry into the waterways of the Citarum River catchment. Policy implementation of 'polluters pay' through Corporate Social Responsibility (CSR) practices to fund community based tourism ventures and 'clean up' projects with outcomes of improving physical infrastructure that will have direct impacts on strengthening socio-economic activities. Adequate waste management infrastructure must be provided to enable residents to dispose of their waste in more ecologically sound and healthier and safer ways for communities. Domestic pollution is discouraged by rewards and by law enforcement including the implementation of sanctions imposed on polluters collectively by the community.

\section{CBT and promoting participatory collective actions}

Improve cooperative businesses for trash recycling and reusing so that members' economical wellbeing is enhanced. Volunteers may assist with improving literacy and numeracy to improve community members' education and contribute to the public awareness programs. Support would be provided for agro-forestry and community based agri-tourism. Provisions may be made for support for home stay construction in forested areas and promotion of traditional local culture and history. The CBT model is aimed at strengthening the functioning of established social groups and traditional networks within villages, along with achieving the benefits of sustainable CBT discussed in this paper. Outcomes would simultaneously alleviate poverty while nurturing and repairing ecosystems and communities.

\section{ACKNOWLEDGMENT}

The authors thank Parahyangan Catholic University, Bandung, West Java, Indonesia and the University of the Sunshine Coast Queensland, Australia. The Australian Consortium of In-Country Indonesian Studies (ACICIS) and the New Colombo Plan Mobility Grant are also acknowledged for enabling the opportunity for initial collaboration on this paper.

\section{REFERENCES}

[1] AHT Group Consultants \& Institute for Community and Regional Development (ICOR), (2014), Laporan Akhir Profil Sosial Ekonomi Masyarakat di Kawasan Inlet Waduk Saguling.

[2] Asian Development Bank (ADB), (2007), Integrated Citarum Water Resources Management Program, Phase 3, Report on roadmap and program development. Government of Republic Indonesia (GRI), Ministry of 
Public Works, Directorate General of Water Resources, January 2007.

[3] Asian Development Bank (ADB), (2014), "Recycling and education help revive Indonesia's Citarum River Basin", available at: https://www.adb.org/news/videos/recyclingand-education-help-revive-indonesias-citarum-river-basin (accessed 13 February 2017)

[4] Banerji, B., Cordes, Joseph, Augustine, Nancy, Lenton, Roberto, Meinzen-Dick, Ruth, \& Young, Garry. (2013), Institutional Analysis of Municipal Water Reforms: Framework And Application To Jakarta, Indonesia, ProQuest Dissertations and Theses.

[5] Barry, M (2011), Managing cross-cultural communication: principles and practices, Palgrave Macmillan, Great Britain.

[6] Berkes, F. and Berkes, M.K. (2009), "Ecological complexity, fuzzy logic, and holism in indigenous knowledge,, Futures, Vol. 41: 6-12

[7] Blangy, S. \& Mehta, H. (2006), "Ecotourism and ecological restoration", Journal for Nature Conservation, vol. 14, pp. 233-236.

[8] Burton, L, Westen, D \& Kowalski, R. (2012), Psychology, 3rd Australian and New Zealand edn, John Wiley \& Sons, Australia

[9] Carroll, A.B. and Buchholtz, A.K. (2015). Business and Society: Ethics and Stakeholder Management, 7th edn. South Western, CENGAGE Learning.

[10] Cole, S. (2006), "Information and empowerment: The keys to achieving sustainable tourism", Journal Sustainable Tourism, vol. 14, pp. 629-644.

[11] Falconer J. (2015), "Pembangunan pariwisata berkelanjutan ekologis: inisiatif lokal dalam konservasi mangrove sebagai dasar untuk potensi unik desa wisata di Sendang Biru" (Ecologically sustainable tourism development: local initiatives in conservation of mangroves as the basis for Sendang Biru's potential as a unique tourism village), Australian Consortium of In Country Indonesian Studies (ACICIS) East Java Field Study, Universitas Muhammadiyah Malang.

[12] Hall, C.M. (1996), Introduction to Tourism in Australia: Impacts, Planning and Development. Addison Wesley Longman: Melbourne, Australia.

[13] Hardin, G. (1968), "The Tragedy of the Commons", Nature, vol. 162, pp.1243-1248.

[14] Hewson, J. (21 November 2013), Pollution flows freely in Indonesian Rivers. Aljazeera, available at: http://www.aljazeera.com/indepth/features/2013/11/pollut ion-flows-freely-indonesia-rivers2013112013166643513.html (accessed 3 May 2017)

[15] Heywood, A. (2014), Global Politics. 2nd edn. Basingstoke: Palgrave MacMillan.

[16] International Labour Organization-ILO, (2012), "Strategic Plan Sustainable Tourism and Green Jobs for Indonesia", Ministry of Tourism and Creative Economy of the Republic of Indonesia

[17] Jasa Tirta II Public Corporation (JT2PC), (n.d.), “Citarum River Basin Thematic Paper: Water quality management for the Citarum River Basin", available at: http://www.narbo.jp/data/01_events/materials/gm02_2_1_ 05pa.pdf (accessed 2 March 2017 )

[18] Kartasasmita, P.S. (2006), Bringing the Public Back In. Edisi Pertama - Yogyakarta; Penerbit Graha Ilmu.

[19] Kartasasmita, P. (2017), Intervening Public Issues: Policy Responses and Community Development Approach. Course Package, Public Issues and Policy Responses Lecture, UNPAR.

[20] Leahy, S. (November 8, 2013), "Toxic towns and poisoned rivers: a by product of industry for the rich". The Guardian, available at: https://www.theguardian.com/global-

development/2013/nov/08/toxic-towns-poisoned-riversbyproduct-industry (accessed 5 May 2017)

[21] McGreavy, B., Hutchins, K., Smith, H., Lindenfeld, L., \& Silka, L. (2013), Addressing the complexities of boundary work in sustainability science through communication. Sustainability, 5(10), pp. 4195-4221.

[22] Mills, C. W. (1959), The sociological imagination. New York: Oxford University Press.

[23] Natahadibrata, Nadya (November 6, 2013), "Citarum, Kalimantan world's most polluted". Jakarta Post, available at:

http://www.thejakartapost.com/news/2013/11/06/citarumkalimantan-world-s-most-polluted.html (accessed 5 May 2017)

[24] Netherlands Development Organization (SNV). (2007), "Asia Pro-Poor Sustainable Tourism Network. A Toolkit for Monitoring and Managing Community-Based Tourism", SNV Asia Pro-Poor Sustainable Tourism Network and Griffith University: Queensland, Australia.

[25] Noda, K. Oki, K. Azechi, I. Yoshida, K., Shirakawa, H., Sigit, G. (2013), "Evaluation of scenarios for alleviating Farmers' Poverty in Citarum River Basin, IndonesiaPotential Water resource and Rice Straw Utility in Cihea Irrigation Area", Environmental Science, Vol.26, No.3 pp. 236-243

[26] Ostrom, E. (1990), Governing the commons: The evolution of institutions for collective action. Cambridge [England]; New York: Cambridge.

[27] Piasto, A. (2015), "Summary of Indonesia's Poverty Analysis", ADB Papers on Indonesia, No 4, October 2015.

[28] Pressreader, (April 6, 2017), Police investigate Saguling Dam pollution, Jakarta Post, available at: https://www.pressreader.com/indonesia/the-jakarta post/20170406/281689729663435 (accessed 10 May 2017)

[29] Purwanto, Y. (n.d.), "Strengthening Capacity for Indonesian Biosphere Reserve Management: Overview of the Ecotourism Development", The Indonesian MAB Program National Committee, The Indonesian Institute of $\begin{array}{ll}\text { Sciences (LIPI), available } & \text { at: } \\ \text { http://www.unesco.org/fileadmin/MULTIMEDIA/HQ/SC }\end{array}$ http://www.unesco.org/fileadmin/MULes/02_PRES_WCBR4_MAB_INDONESIA_Purwa nto.pdf (accessed 10 May 2017)

[30] Reese, S.D., (2001), "Framing Public Life", The Framework Institute, available at: www.frameworkinstitute.org (accessed 5 May 2017)

[31] Sarker, A. (2013), "The Role of State-Reinforced SelfGovernance in Averting The Tragedy Of The Irrigation Commons In Japan", Public Administration, 91(3), p.727.

[32] Sinaga, N. (2013), Ministry of Forestry Integrated Citarum Water Resources Mangement Investment Program. Team INDONESIA. Changwon, October 2013.

[33] Swarbrooke, J. (2002), Sustainable Tourism Management, CABI Publishing, Oxon UK.

[34] The International Ecotourism Society (TIES) (n.d.), available at: https://www.ecotourism.org/what-isecotourism (accessed 8 May 2017)

[35] United Nations (2015), "United Nations World Tourism Organisation (UNWTO) welcomes the adoption of the Sustainable Development Goals" Press Release No.15067 28 Sep 152015 Madrid, Spain, available at: http://media.unwto.org/press-release/2015-09-28/unwtowelcomes-adoption-sustainable-development-goals, (accessed 8 May 2017)

[36] Vreeman, J. (22 February 2017), Van Ginkel, K. Cleaning up the Citarum River, University of Twente, available at: 
https://www.utwente.nl/en/news/!/2017/2/208278/cleanin g-up-the-citarum-river (accessed 22 March 2017).

[37] Williams, Alex (30 June 2013), "Citarum: Possibly the world's most polluted river", Inside Investor, available at: http://investvine.com/citarum-possibly-the-worlds-mostpolluted-river/ (accessed 22 March 2017).

[38] Willis, K., (2011), Theories and Practices of Development, 2nd edition. Oxon: Routledge 